\title{
Breeding Bird Selection of Restored and Native Wooded Draws in North Dakota
}

\section{By Donald Kirby, David Nilson, and Kelly Krabbenhoft}

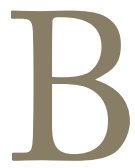

reeding birds have affinities for specific habitats. North Dakota provides numerous unique landscapes for breeding birds, but in western North Dakota, wooded draws are a major habitat. In total landscape, however, wooded draws comprise only 6$8 \%$ of the total land area of western North Dakota. ${ }^{1,2}$ Therefore, these wooded habitats are disproportionately important as breeding sites for resident and migratory birds in western North Dakota.

Surface mining of lignite coal is an important industry to western North Dakota. Nearly 1,000 ha are disturbed by mining operations annually. This form of mining removes all surface vegetation, including woodland habitats. In addition, topography and hydrology are altered in the mining process, which influences the success of woodland reestablishment and resultant plant community structure. Functionality of reestablished woodlands, as measured by breeding bird use, has not been well documented. The intent of our study is to compare species richness, density, and diversity of breeding birds between a restored and a native woodland community on the Glenharold Mine in western North Dakota. We will also discuss other ecological attributes

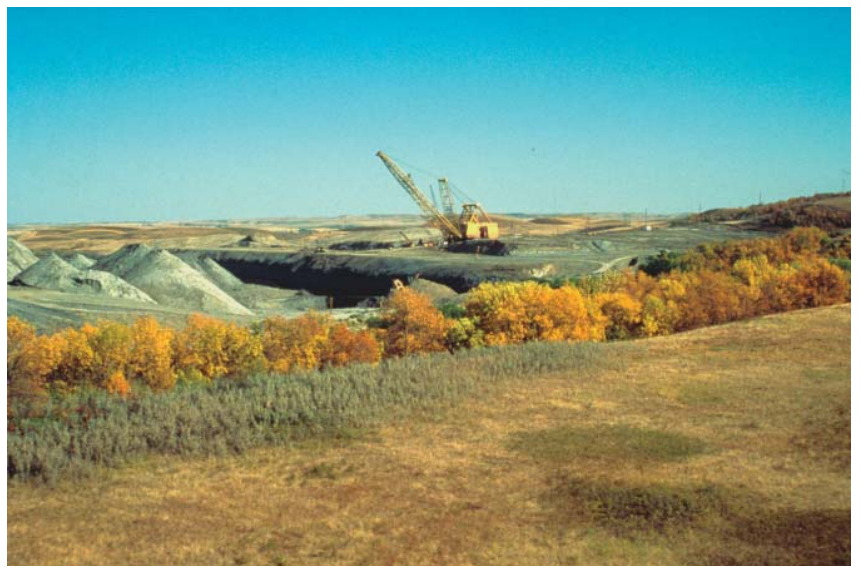

Surface coal mining. Photo courtesy of Dave Nilson. of the two woodlands as they relate to the documented breeding bird populations.

\section{Glenharold Mine, North Dakota}

The Glenharold Mine is south and west of the Missouri River in western North Dakota $\left(47^{\circ} 22^{\prime} \mathrm{N}, 101^{\circ} 27^{\prime} \mathrm{W}\right)$. Agriculture is the primary land use of the region, with prairie dominating the landscape. Within the mine permit area, woodlands comprise approximately $10 \%$ of the land area and are generally located on north- and east-facing concave slopes. ${ }^{3}$ A previous survey had reported 221 species of plants within woodlands on the mine. ${ }^{4}$ The survey classified native woodland into three communities based on vegetation type and height. Deciduous woodlands contain a tree layer consisting predominantly of green ash (Fraxinus pennsylvanica), cottonwood, (Populus deltoides), American elm (Ulmus americana), or box elder (Acer negundo). Tall shrubs form distinct woodlands or a separate layer within the deciduous woodlands. Dominant tall shrubs are American plum (Prunus americana), chokecherry (Prunus virginiana), hawthorn (Crataegus rotundifolia), silver buffaloberry (Shepherdia argentea), and Juneberry (Amelanchier alnifolia). Short shrubs may exist alone or form an ecotone between woodland and grassland habitats and include silverberry (Eleagnus commutata), western snowberry (Symphoricarpos occidentalis), and wood's rose (Rosa woodsii).

We selected two woodland sites for the study. Criteria for selection of the sites included vegetation similar to that of tall shrub communities in the regions, little or no grazing pressure, similar area of habitat edge, and nearly 20 years of continuous breeding bird surveys. The restored woodland in its present stage of structural development resembled a tall shrub community. It was located in the northwest quarter of sec 29, T $144 \mathrm{~N}, \mathrm{R} 84 \mathrm{~W}$. The woodland was reclaimed on an east-facing reclaimed high wall. It had 1,007 $\mathrm{m}$ of edge and 2.1 ha of total area. The woodland was reclaimed in 1982 with chokecherry, American plum, wood's rose, silver buffaloberry, and scattered green ash. Vegetation sampling in 2001, the 19th growing season, indicated that 


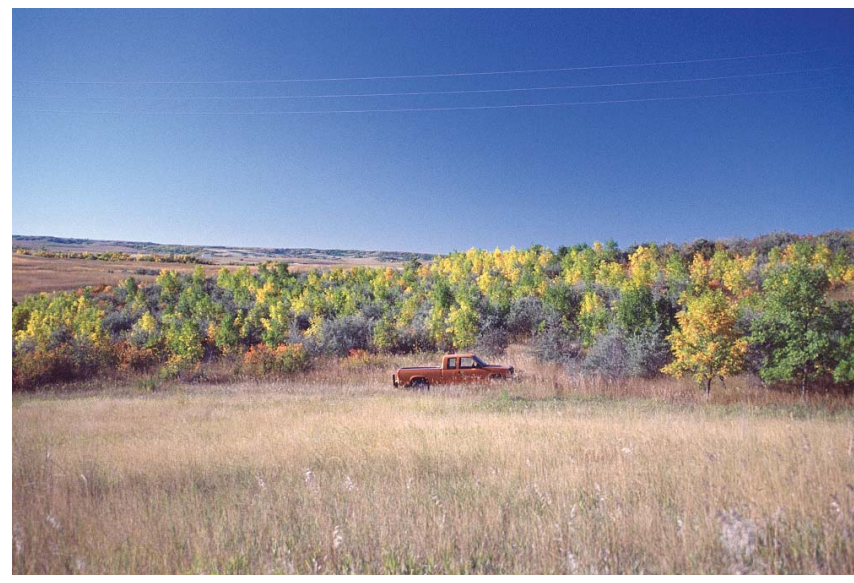

Typical restored woodland. Photo courtesy of Dave Nilson.

the site had approximately 27,500 stems/ha. Over $80 \%$ of the stems were less than $5 \mathrm{~m}$ in height, and less than $1 \%$ were greater than $10 \mathrm{~m}$ in height, with ground cover consisting of $45 \%$ grass, $5 \%$ forb, and $45 \%$ litter.

The native east-facing wooded draw had $1,130 \mathrm{~m}$ of edge, a total area of 0.65 ha, and was located in the southwest quarter of sec $27, \mathrm{~T} 143 \mathrm{~N}, \mathrm{R} 84 \mathrm{~W}$. The dominant species present were green ash, chokecherry, American plum, wood's rose, silver buffaloberry, Juneberry, hawthorn, golden current (Ribes odoratum), and western snowberry. Sampling conducted in 2001 estimated the site to have approximately $46,500 \mathrm{stems} / \mathrm{ha}$, with $60 \%$ of the stems over $5 \mathrm{~m}$ in height, $4 \%$ of the stems over $10 \mathrm{~m}$ in height, and ground cover consisting of $65 \%$ grass, $15 \%$ forb, and $5 \%$ litter.

Breeding bird censuses were taken using the international spot map method. ${ }^{5,6}$ Censusing was initiated in 1982 on the native woodland and 1986 on the restored site. We limited our analysis to census data taken in 1986, 1993, and 2000. Breeding bird observations were made by multiple observers once per day from dawn until about 10:00 AM, coinciding with peak bird song activity. Each site was censused six to eight times during May and June to determine the total number of bird species at each site (bird species richness), the number of breeding bird pairs per hectare (density), and the number of bird species at each site in relation to the relative abundance of each of the species at that site (bird species diversity $^{7}$ ).

\section{Breeding Bird Census Results}

A total of 30 breeding bird species were identified in the restored and native woodland surveys between 1986 and 2000 (Table 1). Fourteen species were surveyed in both woodlands, while eight species were identified in the restored or native woodland only. The native woodland had no introduced breeding birds present, while the restored woodland had two.
No difference in habitat preference was evident between the two sites (Table 1). Both sites had 14 edge species, 2 grassland species, and 5 to 6 generalists using the habitats. Breeding habitat preference indicated that the native site attracted more open woodland and shrub nesting species (19) than did the restored woodland (14). Conversely, the restored woodland attracted more open-canopy breeding species than the native woodland (7 vs. 3 ).

The primary substrate utilized by breeding birds differed between the study areas (Table 1). Fifteen species in the native woodland primarily used the tree canopy-sapling/ shrub substrate, whereas only 10 species used these substrates in the restored woodland. Bird species utilizing ground substrates were greater in the restored woodland (10) compared to the native woodland (7).

Habitat characteristics have been reported to strongly influence density and diversity of breeding birds in native woodlands. In general, breeding bird densities in western North Dakota woodlands were positively correlated with canopy height and cover, and foliage volume in the high ground layer of wooded draws. ${ }^{8,9}$ Also, the number of tree species in woodlands has been positively associated with the number of breeding bird species. ${ }^{10}$ More mature and diverse woodlands provide more nesting sites for birds, such as canopy and cavity nesters.

Habitat characteristics of the two woodlands also played an important role in determining breeding bird distribution and density in this study (Tables 1 and 2). Eleven bird species preferring open woodland/shrub-sapling nesting and foraging habitat were found common to both woodlands. However, in all 11 species, densities were higher in the native woodland. Of the three grassland ground-breeding habitat and foraging bird species common to both woodlands, all three had higher densities in the restored woodland.

The native woodland vegetation was comprised of approximately 46,500 stems/ha, of which $60 \%$ of the stems exceeded $5 \mathrm{~m}$ in height. Breeding birds attracted to a tall, dense habitat for nesting or foraging, such as the least flycatcher, willow flycatcher, and yellow-breasted chat were only found in the native woodland (Tables 1 and 2). It should be noted that the willow flycatcher and yellowbreasted chat have been observed breeding on other restored woodlands at the Glenharold Mine. Other species preferring this habitat but only surveyed sparingly in the native woodland were the black-headed grosbeak, cedar waxwing, and song sparrow. These bird species were not observed in the restored woodland.

The restored woodland had just over $50 \%$ of the stem density $(27,500$ stems/ha) and approximately $25 \%$ of the tall canopy (15\% vs. $60 \%)$ of the native woodland. Bird species utilizing this more open habitat were those preferring shorter shrub and grassland habitats (Tables 1 and 2). These bird species included the common yellow-throat and field 
Table 1. Ecological attributes of nesting bird species found over the study period in restored and native woodlands on the Glenharold Mine

\begin{tabular}{|c|c|c|c|c|c|c|c|c|c|c|c|c|}
\hline \multirow[b]{2}{*}{ Species } & \multirow{2}{*}{$\begin{array}{l}\text { Habitat } \\
\text { prefer- } \\
\text { ence }{ }^{11}\end{array}$} & \multirow[b]{2}{*}{$\begin{array}{l}\text { Breeding } \\
\text { habitat }^{12}\end{array}$} & \multicolumn{6}{|c|}{ Primary substrates utilized ${ }^{8}$} & \multicolumn{2}{|c|}{ Distribution ${ }^{8}$} & \multicolumn{2}{|c|}{$\begin{array}{c}\text { Presence/ } \\
\text { Absence }\end{array}$} \\
\hline & & & Ground & $\begin{array}{l}\text { Shrub- } \\
\text { sapling }\end{array}$ & $\begin{array}{l}\text { Tree } \\
\text { canopy }\end{array}$ & Bark & Cavity & Aerial & Seasonal & $\begin{array}{c}\text { Geo- } \\
\text { graphical }\end{array}$ & Restored & Native \\
\hline $\begin{array}{l}\text { Gray } \\
\text { partridge }\end{array}$ & Edge & Grass & $\mathrm{F}, \mathrm{N}$ & & & & & & P & I & + & - \\
\hline $\begin{array}{l}\text { Ring-necked } \\
\text { pheasant }\end{array}$ & Edge & Grass & $\mathrm{F}, \mathrm{N}$ & & & & & & $\mathrm{P}$ & I & + & - \\
\hline $\begin{array}{l}\text { Mourning } \\
\text { dove }\end{array}$ & Generalist & OpWo & $\mathrm{F}$ & & $\mathrm{N}$ & & & & $\mathrm{s}$ & $P$ & + & + \\
\hline $\begin{array}{l}\text { Common } \\
\text { flicker }\end{array}$ & Generalist & OpWo & $\mathrm{F}$ & & & $\mathrm{F}$ & $\mathrm{N}$ & & $S$ & $P$ & - & + \\
\hline $\begin{array}{l}\text { Least } \\
\text { flycatcher }\end{array}$ & $\begin{array}{l}\text { Forest } \\
\text { interior }\end{array}$ & OpWo & & & N & & & $\mathrm{F}$ & $S$ & $\mathrm{~N}$ & - & + \\
\hline $\begin{array}{l}\text { Willow } \\
\text { flycatcher }\end{array}$ & Edge & Shrub & & $\mathrm{N}$ & & & & $\mathrm{F}$ & $\mathrm{s}$ & $\mathrm{P}$ & - & + \\
\hline $\begin{array}{l}\text { Eastern king- } \\
\text { bird }\end{array}$ & Edge & OpTr & & N & $\mathrm{N}$ & & & $\mathrm{F}$ & $S$ & $P$ & + & + \\
\hline $\begin{array}{l}\text { Western } \\
\text { kingbird }\end{array}$ & Edge & OpTr & & N & N & & & $\mathrm{F}$ & $S$ & W & + & - \\
\hline $\begin{array}{l}\text { Cliff } \\
\text { swallow }\end{array}$ & Generalist & Resi & & & & & $\mathrm{N}$ & $\mathrm{F}$ & $\mathrm{s}$ & $\mathrm{P}$ & + & - \\
\hline $\begin{array}{l}\text { Tree } \\
\text { swallow* }\end{array}$ & Generalist & Wetl & & & & & $\mathrm{N}$ & $\mathrm{F}$ & $\mathrm{s}$ & P & + & - \\
\hline $\begin{array}{l}\text { House } \\
\text { wren }\end{array}$ & Edge & OpWo & & $\mathrm{F}$ & & & N & & $S$ & $P$ & - & + \\
\hline $\begin{array}{l}\text { Eastern blue- } \\
\text { bird }^{*}\end{array}$ & Edge & OpWo & $\mathrm{F}$ & & & & $\mathrm{N}$ & & $\mathrm{s}$ & E & + & + \\
\hline $\begin{array}{l}\text { American } \\
\text { robin }\end{array}$ & Generalist & OpWo & $\mathrm{F}$ & & N & & & & $\mathrm{s}$ & $P$ & + & + \\
\hline $\begin{array}{l}\text { Gray } \\
\text { catbird }\end{array}$ & Edge & Shrub & & $\mathrm{F}, \mathrm{N}$ & & & & & $\mathrm{S}$ & $P$ & + & + \\
\hline $\begin{array}{l}\text { Brown } \\
\text { thrasher }\end{array}$ & Edge & Shrub & $\mathrm{F}, \mathrm{N}$ & $\mathrm{F}, \mathrm{N}$ & & & & & $\mathrm{s}$ & E & + & + \\
\hline $\begin{array}{l}\text { Cedar } \\
\text { waxwing }\end{array}$ & Generalist & OpWo & & $\mathrm{F}, \mathrm{N}$ & $\mathrm{F}, \mathrm{N}$ & & & $\mathrm{F}$ & $\mathrm{P}$ & $\mathrm{P}$ & - & + \\
\hline $\begin{array}{l}\text { Yellow } \\
\text { warbler }\end{array}$ & Edge & OpWo & & $\mathrm{F}, \mathrm{N}$ & & & & & $\mathrm{S}$ & $P$ & + & + \\
\hline $\begin{array}{l}\text { Common } \\
\text { yellowthroat }\end{array}$ & Generalist & Wetl & $\mathrm{F}, \mathrm{N}$ & $\mathrm{F}, \mathrm{N}$ & & & & & $\mathrm{S}$ & $\mathrm{P}$ & + & - \\
\hline $\begin{array}{l}\text { Yellow- } \\
\text { breasted } \\
\text { chat }\end{array}$ & Edge & Shrub & & $\mathrm{F}, \mathrm{N}$ & & & & & $\mathrm{s}$ & P & - & + \\
\hline $\begin{array}{l}\text { Black- } \\
\text { headed } \\
\text { grosbeak }\end{array}$ & Edge & OpWO & & & $\mathrm{F}, \mathrm{N}$ & & & & $S$ & W & - & + \\
\hline
\end{tabular}




\begin{tabular}{|c|c|c|c|c|c|c|c|c|c|c|c|c|}
\hline \multirow[b]{2}{*}{ Species } & \multirow{2}{*}{$\begin{array}{l}\text { Habitat } \\
\text { prefer- } \\
\text { ence }{ }^{11}\end{array}$} & \multirow[b]{2}{*}{$\begin{array}{l}\text { Breeding } \\
\text { habitat }^{12}\end{array}$} & \multicolumn{6}{|c|}{ Primary substrates utilized ${ }^{8}$} & \multicolumn{2}{|c|}{ Distribution ${ }^{8}$} & \multicolumn{2}{|c|}{$\begin{array}{l}\text { Presence/ } \\
\text { Absence }\end{array}$} \\
\hline & & & Ground & $\begin{array}{l}\text { Shrub- } \\
\text { sapling }\end{array}$ & $\begin{array}{c}\text { Tree } \\
\text { canopy }\end{array}$ & Bark & Cavity & Aerial & Seasonal & $\begin{array}{c}\text { Geo- } \\
\text { graphical }\end{array}$ & Restored & Native \\
\hline $\begin{array}{l}\text { Rufous- } \\
\text { sided } \\
\text { towhee }\end{array}$ & Edge & OpWo & $\mathrm{F}, \mathrm{N}$ & $\mathrm{N}$ & & & & & s & $P$ & + & + \\
\hline $\begin{array}{l}\text { Clay-colored } \\
\text { sparrow }\end{array}$ & Edge & Shrub & & $\mathrm{F}, \mathrm{N}$ & & & & & $\mathrm{s}$ & W & + & + \\
\hline $\begin{array}{l}\text { Field } \\
\text { sparrow }\end{array}$ & Edge & Shrub & $\mathrm{F}, \mathrm{N}$ & $\mathrm{N}$ & & & & & $\mathrm{s}$ & $\mathrm{E}$ & + & + \\
\hline $\begin{array}{l}\text { Grasshopper } \\
\text { sparrow }\end{array}$ & Grassland & Grass & $\mathrm{F}, \mathrm{N}$ & & & & & & s & $P$ & + & + \\
\hline $\begin{array}{l}\text { Song } \\
\text { sparrow }\end{array}$ & Edge & Shrub & & $\mathrm{F}, \mathrm{N}$ & & & & & s & $P$ & - & + \\
\hline $\begin{array}{l}\text { Vesper } \\
\text { sparrow }\end{array}$ & Edge & Grass & $\mathrm{F}, \mathrm{N}$ & & & & & & S & $P$ & + & + \\
\hline $\begin{array}{l}\text { Western } \\
\text { meadowlark }\end{array}$ & Grassland & Grass & $\mathrm{F}, \mathrm{N}$ & & & & & & S & W & + & + \\
\hline $\begin{array}{l}\text { Brown- } \\
\text { headed } \\
\text { cowbird }\end{array}$ & Generalist & OpWo & $\mathrm{F}$ & $\mathrm{N}$ & $\mathrm{N}$ & & & & S & $P$ & + & + \\
\hline $\begin{array}{l}\text { American } \\
\text { goldfinch }\end{array}$ & Edge & Shrub & $\mathrm{F}$ & $\mathrm{N}$ & $\mathrm{N}$ & & & & $\mathrm{s}$ & $P$ & + & + \\
\hline
\end{tabular}

OpWo indicates open woodlands; OpTr, open habitat with scattered trees or shrubs; Wetl, wetland; Shrub, shrubland; Grass, grassland; Resi, residential; F, foraging; N, nesting; S, summer resident; P, permanent resident; E, eastern; W, western; N, northern; P, pandemic; and I, introduced.

${ }^{*}$ Present due to nest boxes.

sparrow. A total of 14 bird species preferring open woodland/shrub-sapling habitat for nesting and foraging were surveyed in the restored woodland; however, the estimated breeding pair density of these species was much less than the native woodland.

Richness, density, and diversity of breeding birds in both woodlands increased over time (Table 2). Species richness increased from 6 species/ha and 11 species/ha in 1986 in the restored and native woodland, respectively, to 13 species/ha in both woodlands in 2000. Between 1986 and 2000, density of breeding pairs increased from 5.5 pairs/ha to 13.7 pairs/ ha in the restored woodland, and 23.1 pairs/ha to 39.3 pairs/ ha in the native woodland. Diversity of breeding bird species improved from 1.77 to 2.21 in the restored woodland between 1986 and 2000, and remained relatively constant in the native woodland (2.30 vs. 2.32 ).

Breeding bird density in 2000 was higher in the native (39.3 pairs/ha) compared to the restored (13.7 pairs/ha) woodland (Table 2 ). Others have stated that the variety and density of birds occupying a woodland habitat are strongly influenced by the variety in richness, density, canopy, and understory vegetation of that habitat. ${ }^{8}$ In our study, the restored woodland had fewer species of woodland plants available (5 vs. 10 ), significantly fewer stems in the treeshrub canopy (27,500 stems/ha vs. 46,500 stems/ha), no canopy exceeding $10 \mathrm{~m}$ in height, and a much reduced tall shrub stem density $(>5 \mathrm{~m}$ ) compared to the native woodland $(15 \%$ vs. $60 \%)$. The reduced physical structure and plant species composition of the restored woodland presumably would provide less foraging and nesting sites for many breeding birds.

\section{Summary}

The restored woodland in this study did appear to be functioning as a nesting and foraging site for breeding birds. By 2000, 18 years after establishment, species richness of breeding birds surveyed in the restored woodland equaled that of a native woodland. Despite equal richness, bird species 


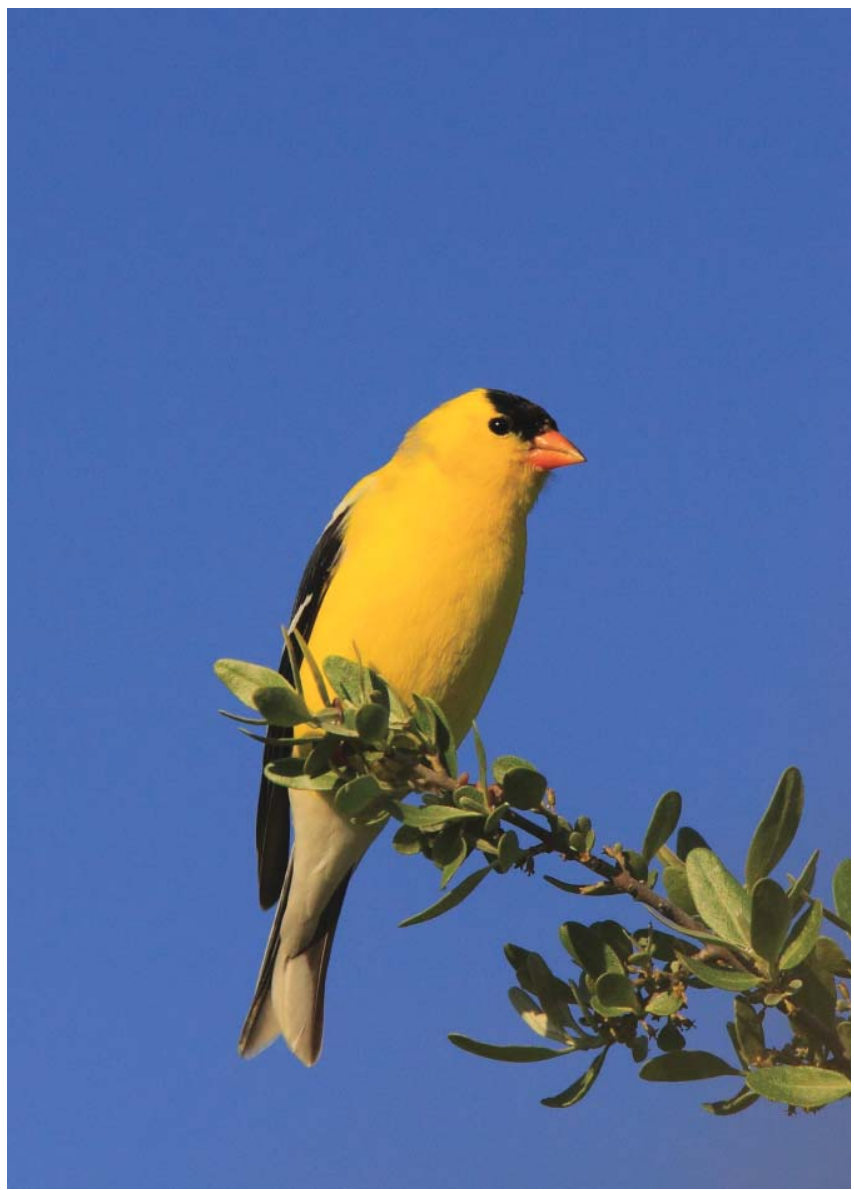

American goldfinch. Photo courtesy of Kelly Krabbenhoft.

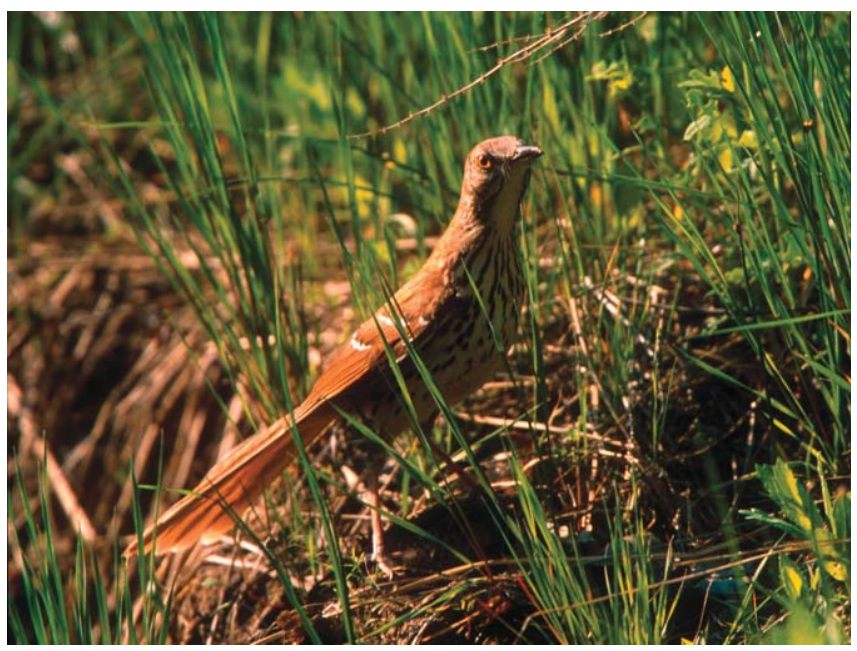

Brown thrasher. Photo courtesy of Kelly Krabbenhoft.

composition was different between the restored and native woodlands, with the restored site having more grassland and short shrub breeding species, and the native woodland attracting more open woodland and shrub-sapling nesting species. The most significant difference in surveys between

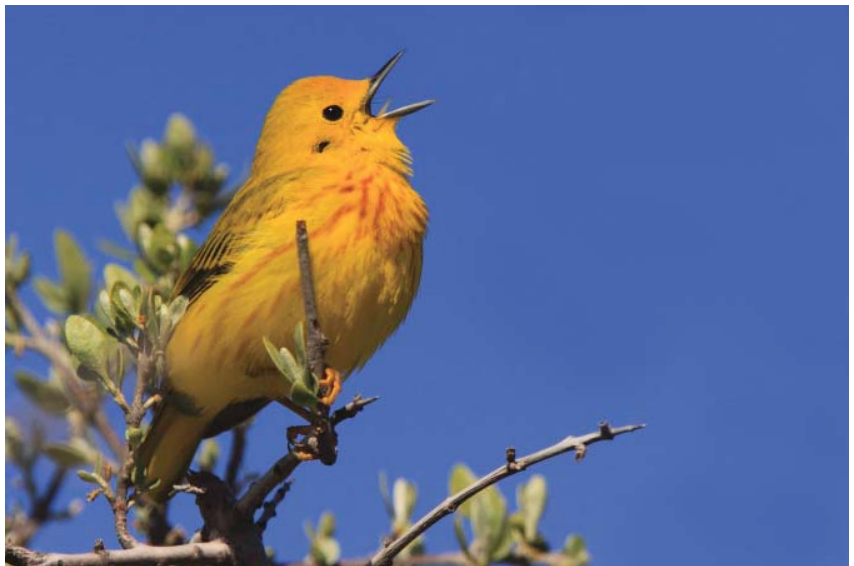

Yellow warbler. Photo courtesy of Kelly Krabbenhoft.

the woodlands in this study was breeding bird density. In 2000, 18 years after establishment, there was a threefold advantage in breeding bird density on the native woodland compared to the restored site. However, breeding bird density of the restored woodland compared favorably with several native woodlands being monitored on the Glenharold Mine (data not presented).

The difference in breeding birds surveyed between the woodlands is most likely related to the differences in habitat characteristics of the two sites. The edge and area of the woodlands were similar, but plant species composition and physical structure were significantly different. The native woodland had significantly more species of trees and shrubs (10 vs. 5), nearly double the number of stems (46,500 stems/ ha vs. 27,500 stems/ha), and a more diverse height and canopy structure. The native woodland had $60 \%$ of the stem density exceeding $5 \mathrm{~m}$ in height, whereas the restored woodland had over $80 \%$ of the tree and shrub stems less than $5 \mathrm{~m}$ in height. Plant species diversity and diversity of physical structure, height, and cover of woodlands have been reported to be positively associated with species richness and density of breeding birds.

Finally, woodland reclamation plans should consider the following elements to provide attractive and functional replacement habitat for breeding birds. Edge and interior habitats should be maximized for those bird species attracted to these woodland features. The reestablished tree and shrub species composition should attempt to mimic the diversity of plant species occupying native woodland habitats. Including trees in the plant species mix is necessary to increase diversity of breeding bird nesting and foraging sites. Lastly, stem density should be maximized through the use of multiple-level canopy shrub (low and medium height) and tree mixes. Providing a variety and diversity of nesting and foraging sites would attract a diversity and greater density of breeding birds to reestablished replacement woodlands. 
Table 2. Comparison of breeding bird pairs in restored and native woodlands on the Glenharold Mine

\begin{tabular}{|c|c|c|c|c|c|c|}
\hline \multirow[b]{3}{*}{ Species } & \multicolumn{6}{|c|}{ Year } \\
\hline & \multicolumn{2}{|c|}{1986} & \multicolumn{2}{|c|}{1993} & \multicolumn{2}{|c|}{2000} \\
\hline & Restored & Native & Restored & Native & Restored & Native \\
\hline & 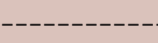 & - & -------- & - & & \\
\hline Ring-necked pheasant & 0 & 0 & 0.53 & 0 & 0 & 0 \\
\hline Mourning dove & 0 & 0 & 0 & 0 & 0.53 & 3.08 \\
\hline Least flycatcher & 0 & 1.54 & 0 & 1.54 & 0 & 0 \\
\hline Willow flycatcher & 0 & 3.08 & 0 & 4.62 & 0 & 4.62 \\
\hline Eastern kingbird & 0 & 1.54 & 0.53 & 3.08 & 0.53 & 1.54 \\
\hline Cliff swallow & 0 & 0 & 0.53 & 0 & 0 & 0 \\
\hline Tree swallow & 0 & 0 & 0 & 0 & 0.53 & 0 \\
\hline American robin & 0 & 1.54 & 0 & 3.08 & 0 & 0 \\
\hline Gray catbird & 0 & 1.54 & 0 & 3.08 & 0.53 & 3.08 \\
\hline Brown thrasher & 0 & 1.54 & 0.53 & 3.08 & 0.53 & 1.54 \\
\hline Cedar waxwing & 0 & 0 & 0 & 0 & 0 & 1.54 \\
\hline Yellow warbler & 0 & 3.08 & 0.53 & 5.38 & 1.58 & 7.69 \\
\hline Common yellowthroat & 0 & 0 & 0 & 0 & 1.05 & 0 \\
\hline Yellow-breasted chat & 0 & 1.54 & 0 & 0 & 0 & 1.54 \\
\hline Black-headed grosbeak & 0 & 0 & 0 & 1.54 & 0 & 0 \\
\hline Lazuli bunting & 1.05 & 0 & 0 & 0 & 0 & 0 \\
\hline Rufous-sided towhee & 0 & 0 & 0 & 0 & 0.53 & 0.77 \\
\hline Clay-colored sparrow & 0 & 4.62 & 2.11 & 1.54 & 4.74 & 7.69 \\
\hline Field sparrow & 0.53 & 0 & 0.53 & 0 & 0.53 & 0 \\
\hline Grasshopper sparrow & 1.05 & 0 & 1.05 & 1.54 & 1.05 & 2.31 \\
\hline Song sparrow & 0 & 0 & 0 & 0 & 0 & 0.77 \\
\hline Vesper sparrow & 1.05 & 0 & 0.53 & 1.54 & 0 & 0 \\
\hline Western meadowlark & 0.79 & 0 & 0.53 & 0 & 0.53 & 0 \\
\hline Brown-headed cowbird & 0 & 1.54 & 0.53 & 1.54 & 0 & 0 \\
\hline American goldfinch & 1.05 & 1.54 & 1.05 & 3.08 & 1.05 & 3.08 \\
\hline Species richness (no./ha) & 6 & 11 & 12 & 13 & 13 & 13 \\
\hline Density (no./ha) & 5.5 & 23.1 & 9.0 & 34.6 & 13.7 & 39.3 \\
\hline $\begin{array}{l}\text { Shannon-Weiner Diversity } \\
\text { Index }\left(H^{\prime}\right)\end{array}$ & 1.77 & 2.30 & 2.34 & 2.46 & 2.21 & 2.32 \\
\hline
\end{tabular}




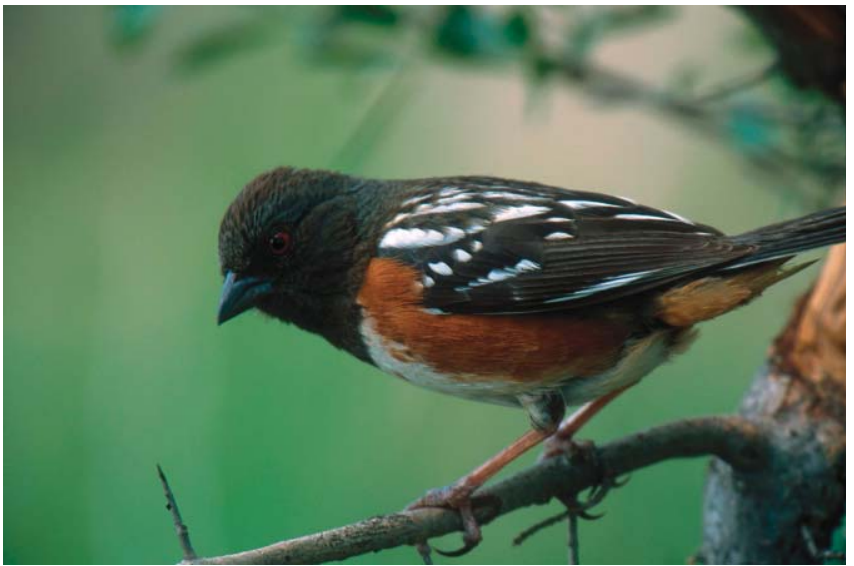

Towhee. Photo courtesy of Kelly Krabbenhoft.

\section{References}

1. FaAnes, C. A. 1983. Breeding birds of wooded draws in western North Dakota. Prairie Naturalist 15:173-187.

2. Hopkins, R. 1983. Woodland bird ecology—southwestern North Dakota [dissertation]. Fargo, ND, USA: North Dakota State University. 104 p.

3. Nilson, D. J., D. R. Kirby, and K. D. Krabbenhoft. 1995. Effects of soil depth and drought on reclaimed woodlands in west central North Dakota. Gillette, WY, USA: Proceedings of the American Society Surface Mining and Reclamation. 6 p.

4. Mack, S. 1981. Hardwood ravines of west-central North Dakota [thesis]. Fargo, ND, USA: North Dakota State University. 168 p.
5. Hall, G. S. 1964. Breeding bird censuses-why and how. Audubon Field Notes 18:413-416.

6. VAn Velzen, W. T. 1972. Breeding bird census instructions. American Birds 26:1007-1010.

7. Shannon, C. E. 1948. A mathematical theory of communication. Bell Systems Technical Journal 27:397-423, 623-656.

8. Hopkins, R., F. Cassel, and A. Bjugstad. 1986. Relationships between breeding birds and vegetation in four woodland types of the Little Missouri National Grasslands. Fort Collins, CO, USA: USDA Forest Service Research Paper RM-270. $12 \mathrm{p}$.

9. FAanes, C. A. 1987. Breeding birds and vegetation structure in western North Dakota wooded draws. Prairie Naturalist 19:209-220.

10. James, F. C., and N. O. Warner. 1982. Relationships between temperate forest bird communities and vegetation structure. Ecology 63:159-171.

11. Faanes, C. A., and R. E. Stewart. 1982. Revised checklist of North Dakota birds. Prairie Naturalist 14:81-92.

12. Ilg, L., AND D. Johnson. 1997. Changes in breeding bird population in North Dakota: 1967 to 1992-93. The Auk 114:74-92.

Authors are Director, School of Natural Resource Sciences, North Dakota State University, Fargo, ND 58108, USA, donald. kirby@ndsu.edu (Kirby); Reclamation Supervisor, Basin Electric Power Cooperative, Glenharold Mine, Stanton, ND 58571, USA (Nilson); and Rangeland Consultant, KDK Consulting, Fargo, ND 58104, USA (Krabbenhoft). An earlier version of this article first appeared as part of the proceedings for the Billings Mined Land Symposium. 